\title{
Pectin-rich biomass as feedstock for fuel ethanol production
}

\author{
Meredith C. Edwards • Joy Doran-Peterson
}

Received: 15 March 2012 / Revised: 11 May 2012 / Accepted: 13 May 2012 / Published online: 14 June 2012

(C) The Author(s) 2012. This article is published with open access at Springerlink.com

\begin{abstract}
The USA has proposed that $30 \%$ of liquid transportation fuel be produced from renewable resources by 2030 (Perlack and Stokes 2011). It will be impossible to reach this goal using corn kernel-based ethanol alone. Pectin-rich biomass, an under-utilized waste product of the sugar and juice industry, can augment US ethanol supplies by capitalizing on this already established feedstock. Currently, pectin-rich biomass is sold (at low value) as animal feed. This review focuses on the three most studied types of pectin-rich biomass: sugar beet pulp, citrus waste and apple pomace. Fermentations of these materials have been conducted with a variety of ethanologens, including yeasts and bacteria. Escherichia coli can ferment a wide range of sugars including galacturonic acid, the primary component of pectin. However, the mixed acid metabolism of E. coli can produce unwanted side products. Saccharomyces cerevisiae cannot naturally ferment galacturonic acid nor pentose sugars but has a homoethanol pathway. Erwinia chrysanthemi is capable of degrading many of the cell wall components of pectin-rich materials, including pectin. Klebsiella oxytoca can metabolize a diverse array of sugars including cellobiose, one degradation product of cellulose. However, both E. chrysanthemi and $K$. oxytoca produce side products during fermentation, similar to $E$. coli. Using pectin-rich residues from industrial processes is beneficial because the material is already collected and partially pretreated to facilitate enzymatic deconstruction of the plant cell walls. Using biomass already produced for other
\end{abstract}

M. C. Edwards · J. Doran-Peterson $(\bowtie)$

Department of Microbiology, University of Georgia,

1000 Cedar Street, 550, Biological Sciences,

Athens, GA 30602, USA

e-mail: jpeterso@uga.edu purposes is an attractive practice because fewer greenhouse gases (GHG) will be anticipated from land-use changes.

Keywords Pectin $\cdot$ Ethanol $\cdot$ Biofuels $\cdot$ Fermentation

\section{Introduction}

The search for a fossil fuel alternative has become increasingly important in the USA due to many factors including: the finite availability of fossil fuels, strained foreign relations between the USA and petroleum providers, and the negative effect burning fossil fuels has on the environment. The USA currently consumes approximately 20 million barrels of crude oil every day. Of these 20 million barrels, over $60 \%$ is imported (US Energy Information Administration, www.eia.doe.gov). Since almost $70 \%$ of the crude oil is used for transportation fuels, an increase in alternative and renewable transportation fuels is vital to reduce the total amount of imported crude oil consumed in the USA.

There are many proposed methods to alleviate the USA's dependence on petroleum-based fuels. One notable alternative is ethanol based biofuels produced from plant biomass. Currently, in the USA, ethanol is primarily produced from starch in corn kernels. However, corn kernels alone will not produce enough ethanol to meet the goals set forth in The Billion Ton Report which proposed that $30 \%$ of liquid transportation fuels should be produced from renewable resources by 2030 (Perlack and Stokes 2011). Therefore, it is necessary to consider other biomass sources for the production of ethanol in congruence with corn kernel ethanol production.

The USA is capable of producing between 1 to 1.6 billion dry tons of biomass per year, which could provide enough ethanol to displace almost $30 \%$ of current crude oil usage 
Table 1 Production and waste generation from pectin-rich biomass; apple, citrus, and sugar beet in the United States in millions of tons. Possible ethanol generation from these wastes in million tons. Production tons are 2009 data from http:// www.faostat.far.org

\begin{tabular}{|c|c|c|c|c|c|}
\hline & \multicolumn{2}{|l|}{ (wet wt) } & \multicolumn{2}{|c|}{ (dry wt) } & \multirow[t]{2}{*}{ Source } \\
\hline & Production & Waste & Waste & Ethanol & \\
\hline Apple & 4.5 & 1.5 & 0.4 & 0.08 & (Chong 1992; Kennedy et al. 1999) \\
\hline Citrus & 10.7 & 4.6 & 0.8 & 0.30 & (Braddock 1995; Zhou et al. 2008) \\
\hline Sugar beet & 26.8 & 5.4 & 1.6 & 0.62 & (Doran et al. 2000) \\
\hline Total & 43.2 & 12.7 & 2.8 & 1.00 & \\
\hline
\end{tabular}

(Perlack and Stokes 2011). Using biomass that is a byproduct or process residue is an attractive practice because fewer GHG will be produced from land-use change. Currently, lignocellulosics, including residues from existing biomass processing, are being vigorously investigated to augment corn kernel ethanol production.

Lignocellulosic biomass is much more complex than corn kernels and is composed of 25-55\% cellulose, 24-50\% hemicellulose, and 10-35\% lignin on a dry weight (dw; Pettersen 1984; Dale et al. 1996; Sun and Cheng 2002). Lignin decreases enzymatic degradation of the plant cell wall polysaccharides (Chang and Holtzapple 2000; Berlin et al. 2005; Guo et al. 2009). Pectin-rich biomass has a low lignin concentration and increased pectin concentration, ranging from $12 \%$ to $35 \%$ of the biomass dw (Kennedy et al. 1999; Doran et al. 2000; Mohnen 2008; Zhou et al. 2008). Pectinrich biomass is an abundant and widely underused resource and includes residues such as apple pomace, citrus waste, and sugar beet pulp (Table 1). All of these biomass types are waste residues left after the fruit or vegetables have been processed for juice or sugar production.

Cost estimates for ethanol production from citrus waste was modified from the cellulose-to-ethanol process model from NREL and USDA/ARS (Wooley et al. 1999; McAloon et al. 2000; Aden et al. 2002) and estimated to be $\$ 1.23 /$ gal. While more expensive than corn kernel ethanol (\$1.00/gal), citrus waste ethanol is predicted to be cheaper than lignocellulosic ethanol processes $(\$ 1.35-1.62 /$ gal; Zhou et al. 2007). One reason a citrus waste-to-ethanol process may be more economically viable than lignocellulosic ethanol processes is the generation of the citrus-derived co-product limonene, which can be sold to help off-set ethanol production costs (Zhou et al. 2007).

\section{Pectin structure}

A brief description of pectin is provided; however, for a more detailed review on pectin structure and biosynthesis see Mohnen (2008). Pectin is a complex carbohydrate primarily composed of covalently linked galacturonic acids (70 \%). Pectin may also contain rhamnose, xylose, arabinose, and galactose (Mohnen 2008).
The three most prominent types of pectin present in the cell wall are homogalacturonan, rhamnogalacturonan I, and rhamnogalacturonan II. Homogalacturonan (an $\alpha$-1,4-linked linear polymer of galacturonic acid) accounts for roughly $65 \%$ of pectin (Mohnen 2008). The second most prominent type of pectin is rhamnogalacturonan I which comprises 20$35 \%$ of pectin (Mohnen 2008). Rhamnogalacturonan I has a disaccharide backbone composed of galacturonic acid and rhanmose. The rhamnose molecules are highly substituted with a variety of side chains primarily composed of arabinans and galactans (Willats et al. 2001; Mohnen 2008). Rhamnogalacturonan II is composed of a homogalacturonan backbone substituted with 12 different sugars and comprises approximately $10 \%$ of pectin in the cell wall (O'Neill et al. 2004; Mohnen 2008).

\section{Pectin-rich biomass composition}

The cell walls of pectin-rich biomass contain 12-35\% pectin on a dry weight (dw) basis (Kennedy et al. 1999; Doran et al. 2000; Mohnen 2008; Zhou et al. 2008). In comparison, cell walls of biomass that are not characterized as pectin-rich, such as corn kernels, grasses, and woody biomass, only contain $2-10 \% \mathrm{dw}$ pectin in their cell wall (Mohnen 2008). Figure 1 compares the composition of pectin-rich materials (apple pomace, citrus waste, and sugar beet pulp) to other biomass types (corn kernels, Monterey pine, and switchgrass). All of these contain a significant amount of cellulose except the corn kernel, which is predominantly starch.

Pectin-rich residues have notably less lignin than lignocellulosic biomass. Approximately $2 \% \mathrm{dw}$ of citrus waste and sugar beet pulp is lignin, much less than the $26 \% \mathrm{dw}$ of Monterey pine. This is significant because lignin interferes with the enzymatic degradation of cellulose and hemicellulose (Chang and Holtzapple 2000; Berlin et al. 2005; Guo et al. 2009) and is not fermentable into ethanol. Before lignocellulosic material can be fermented to produce ethanol, lignin bonds with carbohydrates must be broken. This often requires costly and harsh physical, chemical and/or biological pretreatments that may degrade lignin and some sugars into 


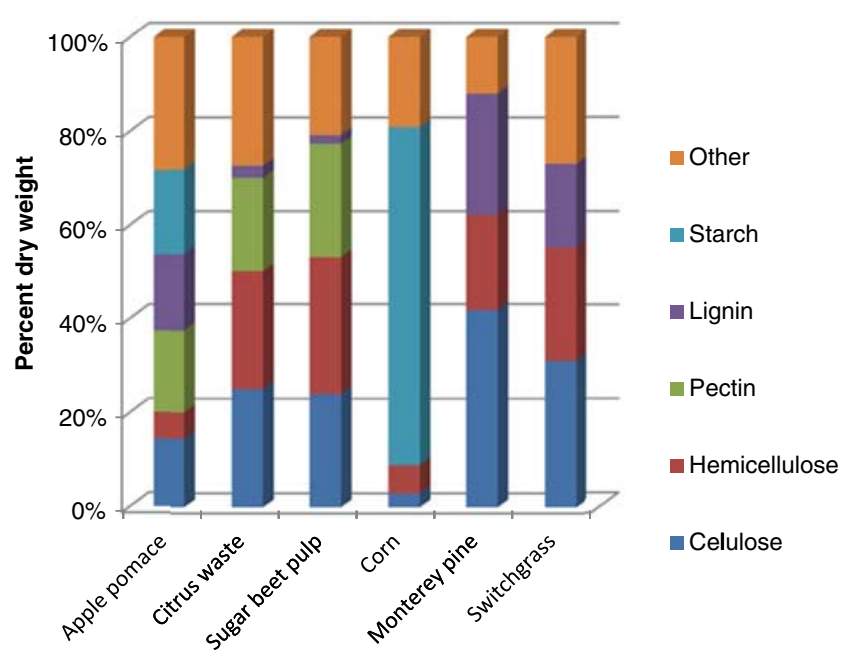

Fig. 1 A comparison of the dry weight composition of pectin-rich biomass to starches and other lignocellulosic biomasses. Pectin-rich biomass includes citrus waste, apple pomace, and sugar beet pulp. (Apple pomace (Kennedy et al. 1999), citrus waste (Zhou et al. 2008), sugar beet pulp (Doran et al. 2000), corn kernels(Lynd et al. 1999), Monterey pine and switchgrass http://www.afdc.energy.gov/biomass/progs/search1.cgi)

inhibitory molecules. A review of these pretreatments can be found in Kumar et al. (2009).

\section{Applications}

An economical and environmentally sustainable use of waste products generated by the industrial processing of fruits has been sought for centuries. There are a variety of uses for the pectin-rich waste material. Some proposed uses of apple pomace include, use as an animal feed, fertilizer, insect bait, ion exchange resin, incorporation into human foods, production of wine, pectin, methane, ethanol, citric acid, butanol, enzymes, apple seed oil, apple vinegar, apple wax, aroma compounds, flavoring, oxalic acid, xyloglucan, activated carbon, antioxidants, heteropolysaccharides, and furfural (Kennedy et al. 1999; Bhushan et al. 2008; Vendruscolo et al. 2008). Citrus waste, sugar beet pulp, and other food wastes can be used in many similar applications (Hang 2006).

Currently the most common use of pectin-rich biomass is as animal feed. Pectin-rich biomass tends to be low in crude protein, fat and phosphorus but high in fiber content and calcium (Table 2). However, it has been shown to be a good feed supplement if added in the correct amounts. For example, citrus waste should compose less than $50 \%$ of beef cattle diet; diets of greater than $60 \%$ citrus waste can cause cattle to develop ruminal parakeratosis (Arthington et al. 2002).

Unfortunately, selling these waste products results in relatively nominal economic returns due to the high cost of dehydrating and pelletizing the material (Doran et al. 2000; Vendruscolo et al. 2008). Sugar beet pulp drying and pelleting can comprise up to 30 to $40 \%$ of the overall energy cost of the waste processing (Coons 1982) and the selling price for these pectin-rich residues varies (Grohmann et al. 1998). The low economic value of pectin-rich materials as an animal feed source makes finding alternative applications for this biomass appealing. One possible alternative is ethanol production for biofuels.

\section{Ethanol production}

The industrial processing of fruits resulting in pectin-rich waste produces a favorable biomass for ethanol production. First, the biomass is conveniently stockpiled in relatively large amounts at the processing facilities, significantly decreasing the cost of collection and transportation (Doran et al. 2000). Secondly, industrial processing can reduce the pretreatment required before fermentation is begun. Himmel et al. describes the complex process required for lignocellulosic degradation from the thermochemical pretreatment down to the enzymatic digestion to form monomeric sugars for ethanol production (Himmel et al. 2007). Highly recalcitrant biomass like grasses and woods require treatments such as ammonia fiber expansion (AFEX) or dilute sulfuric acid pretreatment (Kumar et al. 2009). Some pectin-rich biomass does require pretreatment to disrupt the biomass structure or to remove compounds inhibitory to fermentation, like limonene in citrus waste (von Loesecke 1934; Grohmann et al. 1994a, b; Wilkins et al. 2007b). However, sugar beet pulp fermentations do not require additional particle size reduction, chemical pretreatment, nor inhibitory compound removal. Most sugar beet pulp fermentations were conducted using autoclaving at $121^{\circ} \mathrm{C}$ for 20 minutes

Table 2 The recommended range (in percent dry matter) of crude protein (CP), fats, neutral detergent fiber (NDF), acid detergent fiber (ADF), calcium, and phosphorus in dairy cattle feed compared to actual quantities found in pectin-rich materials

\begin{tabular}{llllllll}
\hline & CP & FAT & NDF & ADF & Calcium & Phosphorus & Source \\
\hline Recommended & $10-19$ & $3.5-5.0$ & $23-35$ & $0.16-0.25$ & $0.16-0.25$ & $0.65-1.00$ & (Brandt and Martin 1994) \\
Apple pomace & 5.40 & $1.5-2.3$ & 42.52 & 0.14 & 0.14 & 0.09 & (Grohmann and Bothast 1994; Kennedy et al. 1999) \\
Citrus waste & 6.40 & $0.7-1.5$ & 20.35 & 1.58 & 1.58 & 0.12 & (Grohmann and Bothast 1994; Arthington et al. 2002) \\
Sugar beet pulp & 9.63 & $<0.1$ & 63.36 & 0.97 & 0.97 & 0.06 & (Grohmann and Bothast 1994) \\
\hline
\end{tabular}


Table 3 A review of ethanol production from apple pomace fermentations using a variety of ethanologens with no additional commercial enzymes

\begin{tabular}{|c|c|c|c|c|c|c|c|c|c|}
\hline Organism & Pretreatment & $\begin{array}{l}\text { Ferm } \\
\text { type }\end{array}$ & Solids $^{\mathrm{a}}$ & Inoculum & $\mathrm{pH}$ & Temp $\left({ }^{\circ} \mathrm{C}\right)$ & $\begin{array}{l}\mathrm{Max} \\
\mathrm{EtOH}(\%)^{\mathrm{b}}\end{array}$ & Time (h) & Reference \\
\hline $\begin{array}{l}\text { S. cerevisiae } \\
\text { MTCC } 173\end{array}$ & none & solid state & 100 & $1 \% v / w$ & 6.5 & 30 & 8.44 & 72 & (Chatanta et al. 2008) \\
\hline S. cerevisiae & $\begin{array}{l}\text { rehydrated }(1: 4) \\
\text { with ammonium } \\
\text { sulfate }(1.8 \%)\end{array}$ & solid state & 1000 & $5 \% v / w$ & $4.2-3.9$ & 25 & 4.50 & 96 & $\begin{array}{l}\text { (Joshi and } \\
\text { Sandhu 1996) }\end{array}$ \\
\hline $\begin{array}{l}\text { S. cerevisiae } \\
\text { ATCC } 24702\end{array}$ & none & solid state & 2500 & $1 \mathrm{~L}^{\mathrm{c}}$ & $\mathrm{n} / \mathrm{a}$ & 30 & $2.08 w / w$ & $40^{\mathrm{d}}$ & $\begin{array}{l}\text { (Ngadi and } \\
\text { Correia 1992) }\end{array}$ \\
\hline $\begin{array}{l}\text { S. cerevisiae } \\
\text { Montrachet } \\
\text { strain } 522\end{array}$ & none & solid state & 800 & $25 \mathrm{ml}(4 \mathrm{~g} \mathrm{dw})$ & $\mathrm{n} / \mathrm{a}$ & 30 & $4.30 w / w$ & 24 & (Hang et al. 1981) \\
\hline
\end{tabular}

${ }^{\text {a }}$ All solids loading are in $\mathrm{g}$

${ }^{\mathrm{b}}$ All maximum ethanol yields are in $\% v / w$ unless otherwise specified

${ }^{\mathrm{c}} 2 \mathrm{ml}$ of stock culture was incubated at $30^{\circ} \mathrm{C}$ for 3 days in $10 \mathrm{ml}$ pressed apples, transferred to 11 pressed apples and incubated at $30{ }^{\circ} \mathrm{C}$ for 3 days before inoculating fermentation

${ }^{d}$ These times are estimates from graphs

to minimize contamination, followed by enzymatic digestion and fermentation of the resulting carbohydrates.

\section{Fermenting with Saccharomyces cerevisiae}

Ethanol production data from pectin-rich biomass fermentations has been compiled based on biomass type in Table 3 (apple pomace), Table 4 (citrus waste), and Table 5 (sugar beet pulp) and some of these fermentations will be discussed in more detail. Early fermentations were conducted with $S$. cerevisiae. Some advantages of using $S$. cerevisiae include its ability to tolerate high substrate concentrations and high ethanol concentrations, as well as relatively low $\mathrm{pH}$ and oxygen levels (Gujjari et al. 2009), making it a robust organism for the fermentation process. It also converts sugars to ethanol using a homoethanol pathway; therefore, sugars are not siphoned into unwanted co-products. In fermentations where sucrose content is high, $S$. cerevisiae performs well. However, $S$. cerevisiae is not the ideal ethanologen for pectin-rich biomass pulp or residue fermentations, due to its inability to naturally ferment pentose sugars and galacturonic acid.

Strains of $S$. cerevisiae capable of fermenting xylose and arabinose have been developed. Xylose fermenting strains perform fairly well; however, arabinose fermenting strains still require optimization (Sedlak and Ho 2001; van Maris et al. 2006; Nevoigt 2008). Arabinose utilization is important when fermenting pectin-rich biomass due to the arabinans present on rhamnogalacturonan I (Mohnen 2008). In fact, arabinose comprises 18-21\%(dw) of sugar beet pulp (Renard and Thibault 1993; Micard et al. 1996). Engineering $S$. cerevisiae to utilize galacturonic acid has also been suggested and a general plan has been outlined (van Maris et al. 2006).

\section{Fermenting with Escherichia coli}

Another option for pectin-rich biomass fermentations is $E$. coli. E. coli does not tolerate ethanol as well as $S$. cerevisiae and has a higher optimal pH (Gujjari et al. 2009). Therefore, $E$. coli and commercial enzymes required for degradation of the plant cell wall (which have an acidic optimum $\mathrm{pH}$ ) cannot reach their maximum activities simultaneously during biomass fermentation. E. coli is capable of fermenting a wide range of sugars including arabinose and galacturonic acid. Galacturonic acid catabolism in E. coli has been reviewed previously (Richard and Hilditch 2009). To increase efficiency of fermentations using $E$. coli, strains have been bioengineered to produce higher titers of ethanol from biomass. Typically, when E. coli ferments sugars it produces mixed acids, including ethanol, acetate, formate, succinate and lactate (Conway et al. 1987; Dien et al. 2003; Jarboe et al. 2007). A strain of E. coli, KO11, was engineered to shunt pyruvate into a homoethanol producing pathway and away from $E$. coli's native pathways (Ohta et al. 1991).

Fermentations of pectin-rich biomass conducted with KO11 produced higher ethanol titers than fermentations performed with $S$. cerevisiae. Citrus waste fermented by $S$. cerevisiae $\left(\mathrm{pH} 6,37^{\circ} \mathrm{C}\right)$ produced $3.96 \%(w / v)$ ethanol (Wilkins et al. 2007b) but citrus waste fermented by E. coli KO11 $\left(\mathrm{pH} 5.8,37{ }^{\circ} \mathrm{C}\right)$ produced $4.70 \%(w / v)$ ethanol (Grohmann et al. 1995; Table 4). However, these ethanol yields are difficult to compare due to differences in the biomass pretreatment and the fermentation conditions. S. cerevisiae fermentations were conducted with steam exploded citrus waste and an enzyme loading of 297 IU pectinase/g dry weight of citrus waste (dw). E. coli KO11 fermentations were conducted with citrus waste that was only enzymatically hydrolyzed, using 


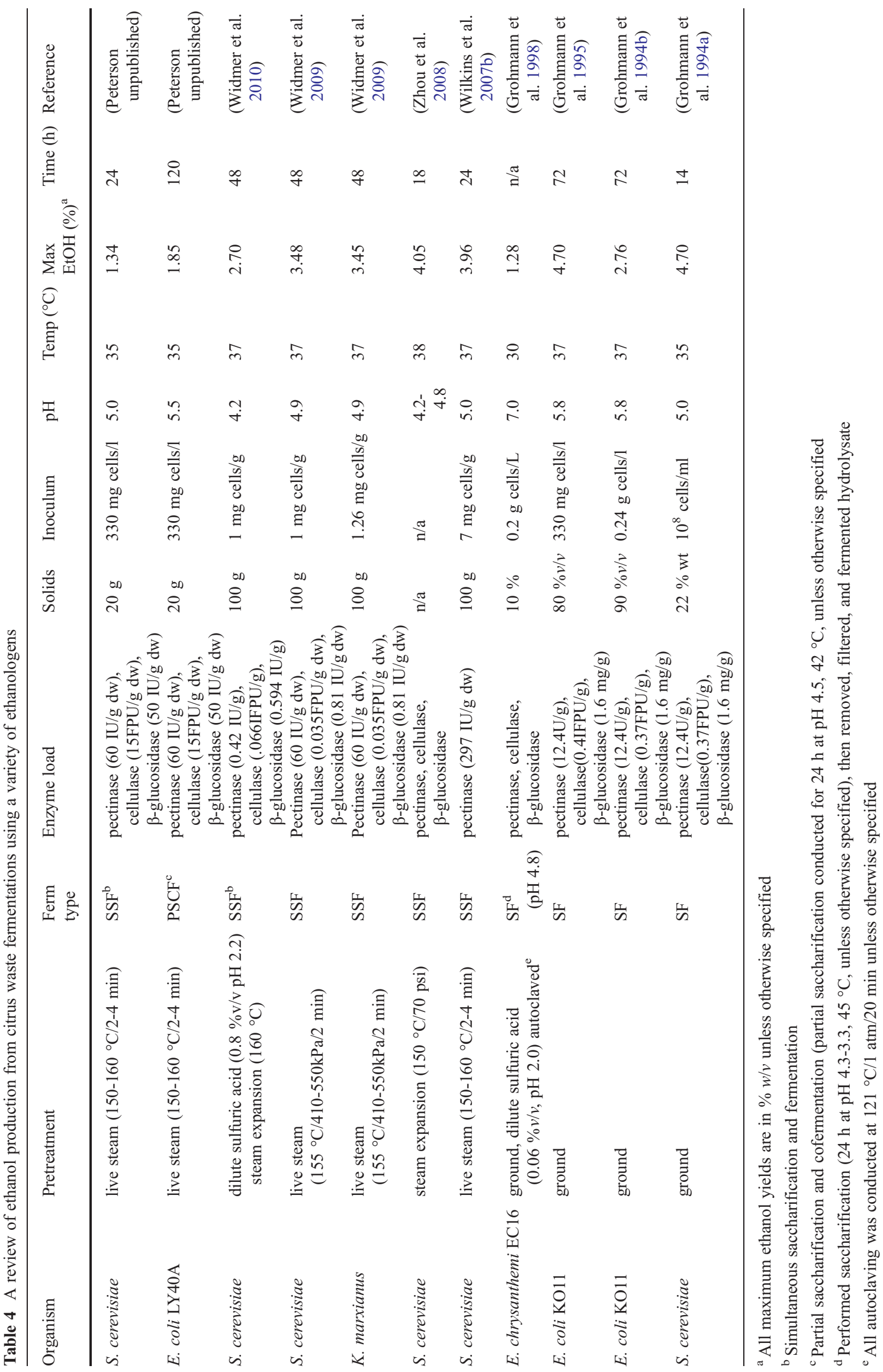




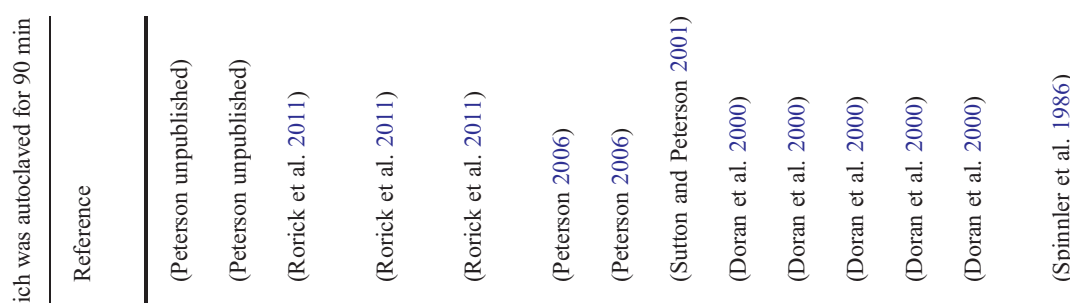

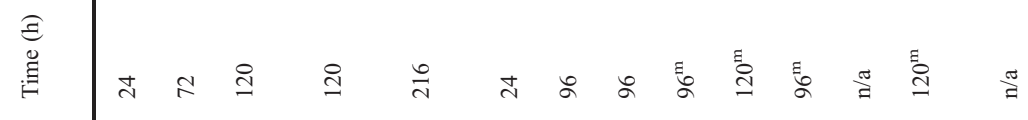

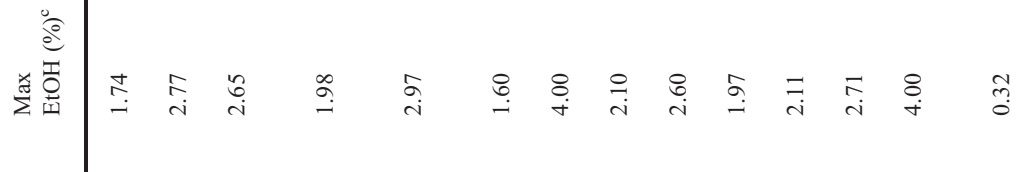

రิ

密

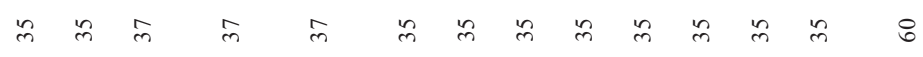

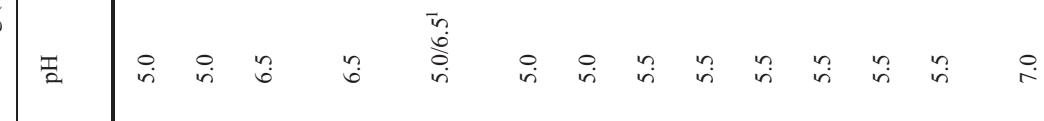

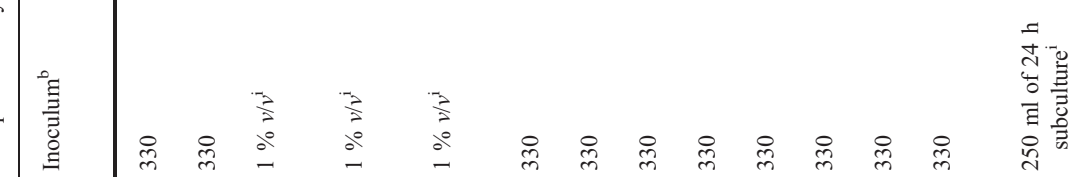

崽

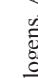

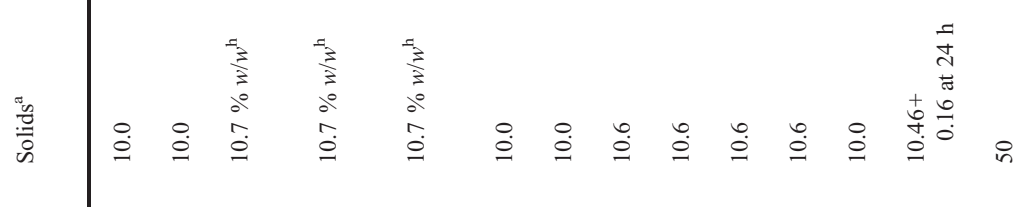


0.4 FPU cellulase/g dw cw, 12.4 IU pectinase/g dw cw, and $1.6 \mathrm{mg}$ of $\beta$-glucosidase protein $/ \mathrm{g} \mathrm{dw} \mathrm{cw}$.

Better comparisons can be drawn from fermentations that were conducted with biomass that has had the same pretreatment. Grohmann et al. (1995) performed fermentations of citrus waste hydrolysate using E. coli KO11 and $S$. cerevisiae. The hydrolysate was formed by first grinding the citrus peel and then hydrolyzing the ground citrus waste with pectinase, cellulase, and $\beta$-glucosidase for 24 hours at $45^{\circ} \mathrm{C}$. Fermentation with $E$. coli KO11 increased ethanol titers by $25-35 \%$ compared to $S$. cerevisiae fermentations (Grohmann et al. 1998).

Serial fermentations using S. cerevisiae and E. coli KO11 have been conducted to increase ethanol production from sugar beet pulp (Rorick et al. 2011). Serial addition of $E$. coli KO11 and then $S$. cerevisiae were unsuccessful due to the high concentrations of acetic acid produced by $E$. coli KO11. After fermentation with E. coli KO11 acetic acid levels reached $11 \mathrm{~g} / \mathrm{l}$, over twice the concentration $S$. cerevisiae can tolerate (Narendranath et al. 2001). Serial addition of $S$. cerevisiae followed by E. coli KO11 produced $2.97 \%(w / v)$ ethanol, $0.37 \%(w / v)$ more than fermentations conducted with E. coli KO11 alone (Table 5). However, maximum ethanol production was not reached until $216 \mathrm{~h}$. E. coli KO11 only fermentations reached maximum ethanol concentrations much earlier $(120 \mathrm{~h})$. Therefore, E. coli KO11 only fermentations had higher volumetric productivity and essentially the same yield.

Peterson (2006) compared another strain of E. coli, strain LY01 to S. cerevisiae (Peterson 2006; Table 5) using sugar beet pulp as the substrate. Strain LY01 was isolated from $E$. coli $\mathrm{KO} 11$ and is more ethanol tolerant than KO11 (Yomano et al. 1998). Sugar beet pulp was autoclaved $\left(121^{\circ} \mathrm{C} / 1 \mathrm{~atm} /\right.$ $20 \mathrm{~min}$ ) and enzymatically hydrolyzed with $10.5 \mathrm{FPU}$ cellulase/g dry weight of sugar beet pulp (dw sbp) and $240.8 \mathrm{IU}$ pectinase/g dw sbp for $24 \mathrm{~h}$ at $42{ }^{\circ} \mathrm{C}$ and a starting $\mathrm{pH}$ of 5.0. LY01 produced $4 \%(w / v)$ ethanol and S. cerevisiae produced $1.6 \%(w / v)$ ethanol.

Recently, E. coli strains LY01 and KO11 have been engineered to further improve their ability to ferment pectin-rich biomass. One strain, E. coli LY40A, was engineered from $E$. coli $\mathrm{KO} 11$ by integrating the casAB operon from Klebsiella oxytoca into the E. coli genome (Edwards et al. 2011). The cas $A B$ operon encodes cellobiose phosphoenolpyruvatedependent phosphotransferase genes which allows LY40A to uptake and metabolize cellobiose (Lai et al. 1997; Edwards et al. 2011). Sugar beet pulp fermentations conducted with LY40A produced $2.77 \%(w / v)$ ethanol, while those conducted with $S$. cerevisiae only produced $1.74 \%$ $(w / v)$ ethanol. In an effort to further reduce the commercial enzyme load needed for pectin-rich biomass degradation, genes from Erwinia chrysanthemi were added to LY40A which allowed the organism, E. coli JP08C, to degrade pectin in sugar beet pulp to galacturonic acid monomers (Edwards et al. 2011). Pectate lyase E first hydrolyzed pectin into short chained oligogalacturonides. Oligogalacturonide lyase then degraded the oligogalacturonides into monomeric sugars which JP08C could ferment to ethanol. JP08C has been shown to increase ethanol yields in fermentations conducted with low commercial enzyme loadings, but the process has yet to be optimized for the production of industrially relevant levels of ethanol (Edwards et al. 2011).

\section{Fermenting with other ethanologens}

Other organisms have been used for ethanol production from pectin-rich materials as well. Research has focused on strains that are thermotolerant, like the yeast Kluyveromyces marxianus, strains that can produce their own cell wall degrading enzymes, like the bacterium E. chrysanthemi, or organisms that are able to metabolize a wide variety of sugars, like the bacterium $K$. oxytoca. $K$. marxianus ferments hexose sugars to ethanol via a homoethanol pathway. Both bacterial ethanologens use the mixed acid fermentation pathway to metabolize sugars and will produce organic acid co-products similarly to $E$. coli.

The thermotolerance of $K$. marxianus is economically advantageous since the price of cooling fermentors could be reduced. Strains of $K$. marxianus isolated from sugar cane mills can produce ethanol at temperature as high as $47{ }^{\circ} \mathrm{C}$ (Anderson et al. 1986). A comparison of ethanol production from K. marxianus and S. cerevisiae in orange processing waste pretreated with steam expansion demonstrated that $K$. marxianus was capable of producing ethanol titers similar to that of S. cerevisiae. However, K. marxianus required a higher inoculation level than $S$. cerevisiae to produce comparable amounts of ethanol (Widmer et al. 2009). Further research is still required to understand the benefits of fermenting pectinrich materials with $K$. marxianus instead of $S$. cerevisiae. Unfortunately, K. marxianus, like S. cerevisiae, is unable to naturally ferment pentose and acidic sugars.

Another option is the bacterium E. chrysanthemi, which can degrade plant cell wall components. Fermentations of dilute sulfuric acid and autoclaved pretreated citrus waste using E. chrysanthemi EC16 produced less ethanol than the fermentations conducted with $S$. cerevisiae (Wilkins et al. 2007b) and E. coli KO11 (Grohmann et al. 1995), described earlier (Table 4). E. chrysanthemi EC16 contains the PET operon from Zymomonas mobilis on the plasmid pLOI555 which increases the organisms ethanol production and decreases the final concentration of co-products (Beall and Ingram 1993). E. chrysanthemi EC16 only produced $1.28 \%$ $w / v$ ethanol (Grohmann et al. 1998). 
Direct comparison of ethanol titers from biomass exposed to the same pretreatment gave similar results. $E$. chrysanthemi EC16 fermentations of sugar beet pulp produced $1.97 \%(w / v)$ ethanol, less than the $2.55 \%(w / v)$ ethanol produced by E. coli KO11 on the same substrate (Doran et al. 2000; Table 5). However, E. chrysanthemi EC16 was able to produce more ethanol than E. coli KO11 when no fungal enzymes were present, but these yields were low (Doran et al. 2000).

Doran et al. (2000) also conducted fermentations of sugar beet pulp with $K$. oxytoca P2, a strain with the PET operon chromosomally integrated (Wood and Ingram 1992). K. oxytoca is capable of fermenting a wide variety of pentose and hexose sugars including cellobiose, cellotriose, xylobiose, and xylotriose (Burchhardt and Ingram 1992; Wood and Ingram 1992). Like E. chrysanthemi EC16, when no commercial enzymes were added $K$. oxytoca $\mathrm{P} 2$ out produced E. coli KO11 but ethanol yields were low. In the presence of commercial enzymes $K$. oxytoca $\mathrm{P} 2$ produced $1.55 \%(w / v)$ ethanol, lower than both E. coli KO11 and $E$. chrysanthemi EC16 ethanol production.

Some organisms combine high thermotolerance with cell wall degradation enzymes. These organisms have mainly been studied for their production of thermotolerant enzymes for food industries, less is known about their ethanol production from pectin-rich material. Fermentations conducted by Spinnler et al. (1986) of sugar beet pulp using Clostridium thermocellum demonstrated the organism's propensity to produce acetate instead of ethanol when fermenting pectinrich material. During the fermentation of $50 \%(w / v)$ sugar beet pulp, $0.78 \%(w / v)$ acetic acid was produced, while only $0.32 \%(w / v)$ ethanol was produced (Table 5; Spinnler et al. 1986). It is unclear if the fermentations could reach industrially viable production levels if commercial enzymes were added to augment the activity provided by the organisms' native cell wall degradation enzymes.

A third approach, bioengineering a homoethanol producing organism with narrow substrate utilization, Z. mobilis, to metabolize new sugars, has been considered but has yet to be tested on pectin-rich materials. Z. mobilis AX101 had been engineered to ferment xylose and arabinose along with glucose which is part of its native pathway (Mohagheghi et al. 2002). Fermentations of pure sugars have shown that AX101 is capable of metabolizing glucose, arabinose, and xylose into ethanol. However, these sugars were not used simultaneously and the organism does not ferment galacturonic acid.

\section{Concerns when fermenting pectin-rich materials}

All of the ethanologens described above produce some acetate during pectin-rich biomass fermentations, except $S$. cerevisiae, K. marxianus, and Z. mobilis AX101 which are unable to metabolize galacturonic acid. The production of side products like acetate decreases the amount of ethanol that can be produced during fermentation. E. coli KO11, E. chrysanthemi EC 16, and K. oxytoca produced $0.23(\mathrm{~g} / \mathrm{g})$, $0.38(\mathrm{~g} / \mathrm{g})$, and $0.34(\mathrm{~g} / \mathrm{g})$ acetate from $20 \mathrm{~g} / \mathrm{L}$ fermentations of galacturonic acid, respectively (Doran et al. 2000). The metabolism of one mole of galacturonic acid produces one mole ethanol and one mole acetate due to the higher oxidation state of galacturonic acid in comparison to other sugars. Therefore, more molecules of $\mathrm{NAD}(\mathrm{P}) \mathrm{H}$ are required to ferment galacturonic acid, this is balanced by using the pyruvate formate lyase pathway which produces both ethanol and acetate (Grohmann et al. 1994b, 1995,1998).

Another concern when fermenting pectin-rich residues is citrus waste specific, the presence of the inhibitor Dlimonene, an aromatic monoterpene that comprises about $86-95 \%$ of the essential oils in citrus waste (Shaw 1979) and is present in citrus waste hydrolysate at concentrations of approximately $1.4 \%(v / v$; Grohmann et al. 1994a). Concentrations of peel oil between $0.05-0.1 \%$ have been shown to have inhibitory effects on ethanol concentrations during the production of wine by yeast (von Loesecke 1934). Terpenes are believed to disrupt cellular membranes resulting in the release of cellular components, and the dissipation of the proton motive force and $\mathrm{K}^{+}$gradient (Andrews et al. 1980; Uribe et al. 1985; Koroch and Juliani 2007).

Ethanol production from citrus waste by $S$. cerevisiae begins to decrease when D-limonene concentrations increase above $0.12 \%$ ( $v / w$; Wilkins et al. 2007b). The addition of peel oil, which contains D-limonene, to pure sugar or filtered citrus waste hydrolysate fermentations conducted with yeast (S. cerevisiae or K. marxianus) also decreased ethanol yields (Grohmann et al. 1994a; Wilkins et al. 2007a).

It has been suggested that gram-negative organisms, like $E$. coli, tend to be more resistant to some terpenes, including limonene, possibly due to the protection provided by their outer membrane (Andrews et al. 1980; Helander et al. 1998; Mann et al. 2000). Kim et al. (1995) observed the inhibitory effects of a variety of essential oil components on pathogenic bacteria. Limonene was shown to have no inhibitory effect against two strains of $E$. coli; however, it did inhibit growth of the gram-positive bacterium, Listeria monocytogenes (Kim et al. 1995). However, more recent studies have shown that limonene levels as low as $0.03 \%(v / v)$ to be inhibitory to E. coli (Dunlop et al. 2011).

Fortunately, limonene can be removed from citrus waste by steam stripping the waste. Limonene is a valuable coproduct of citrus waste fermentation and is generally recognized as safe (GRAS) by the Code of Federal Regulation. It is often used as a flavoring and fragrance, but has also been used as a solvent for cleaning supplies, a treatment for cholesterol containing gallstones, and a holistic treatment for gastroesophageal reflux disease and heartburn (Sun 
2007). Removing limonene from the fermentation not only helps ethanol production but results in a more economically viable process. Zhou et al. estimated that limonene recovery could cut the cost of ethanol production from citrus waste by over \$0.50/gal of ethanol (Zhou et al. 2007).

\section{Conclusions}

Pectin-rich residues are generated as waste products from industrial processing of fruits and vegetables like apples, citrus, and sugar beets. In the USA, approximately 2.8 million tons $(\mathrm{dw})$ of pectin-rich material is produced each year (Table 1). There are many options for disposal of this waste, from landfilling to the production of high-value products like aroma compounds. Currently most of this material is used for animal feed or put in landfills

Here we have reviewed another option, fermenting the biomass for fuel ethanol. Based on the amount of pectin-rich biomass produced annually in the USA, approximately 1 million tons or 335 million gallons of ethanol could be produced from these residues (Table 1). However, for this to be possible all of the sugars must be catabolized to ethanol. Of the possible ethanologens described above, E. coli is currently the best option for pectin-rich biomass fermentation. It can metabolize all of the sugars present in the biomass and has been engineered to produce high ethanol yields with limited unwanted co-products.

Open Access This article is distributed under the terms of the Creative Commons Attribution License which permits any use, distribution, and reproduction in any medium, provided the original author(s) and the source are credited.

\section{References}

Aden A, Ruth M, Ibsen K, Jechura J, Neeves K, Sheehan J, Wallace B, Montague L, Slayton A, Lukas J (2002) Lignocellulosic biomass to ethanol process design and economics utilizing co-current dilute acid prehydrolysis and enzymatic hydrolysis for corn stover. Nat Renewable Energy Lab Tech Rpt. Golden, CO, NREL

Anderson PJ, McNeil K, Watson K (1986) High-efficiency carbohydrate fermentation to ethanol at temperatures above 40 degrees $\mathrm{C}$ by Kluyveromyces marxianus var. marxianus isolated from sugar mills. Appl Environ Microbiol 51(6):1314-1320

Andrews RE, Parks LW, Spence KD (1980) Some effects of douglas fir terpenes on certain microorganisms. Appl Environ Microbiol 40 (2):301-304

Arthington JD, Kunkle WE, Martin AM (2002) Citrus pulp for cattle. Vet Clin North Am Food Anim Pract 18(2):317-326, vii

Beall DS, Ingram LO (1993) Genetic engineering of soft-rot bacteria for ethanol production from lignocellulose. J Ind Microbiol $11: 151-155$
Berlin A, Gilkes N, Kurabi A, Bura R, Tu M, Kilburn D, Saddler J (2005) Weak lignin-binding enzymes: a novel approach to improve activity of cellulases for hydrolysis of lignocellulosics. Appl Biochem Biotechnol 121-124:163-170

Bhushan S, Kalia K, Sharma M, Singh B, Ahuja PS (2008) Processing of apple pomace for bioactive molecules. Crit Rev Biotechnol 28 (4):285-296

Braddock RJ (1995) By-products of citrus fruit. Food Technol 49:74 77

Brandt RC, Martin KS (1994) The food processing residual management manual. PDoE Protection. Harrisburg, PA. 6:1-268

Burchhardt G, Ingram LO (1992) Conversion of xylan to ethanol by ethanologenic strains of Escherichia coli and Klebsiella oxytoca. Appl Environ Microbiol 58(4):1128-1133

Chang VS, Holtzapple MT (2000) Fundamental factors affecting biomass enzymatic reactivity. Appl Biochem Biotechnol 84-86:5-37

Chatanta DK, Attri C, Gopal K, Devi M, Gupta G, Bhalla TC (2008) Bioethanol production from apple pomace left after juice extraction. Internet J Microbiol 5(2)

Chong C (1992) Apple pomace as an amendment in container growing media. Hortic Sci 27:1138

Conway T, Sewell GW, Osman YA, Ingram LO (1987) Cloning and sequencing of the alcohol dehydrogenase II gene from Zymomonas mobilis. J Bacteriol 169(6):2591-2597

Coons FF (1982) In: McGinnis RA (ed) Beet sugar technology. Beet Sugar Development Foundation, Denver, pp 587-599

Dale B, Leong C, Pham T, Esquivel V, Rios I, Latimer V (1996) Hydrolysis of lignocellulosics at low enzyme levels: application of the AFEX process. Bioresour Technol 56:111-116

Dien BS, Cotta MA, Jeffries TW (2003) Bacteria engineered for fuel ethanol production: current status. Appl Microbiol Biotechnol 63 (3):258-266

Doran JB, Cripe J, Sutton M, Foster B (2000) Fermentations of pectinrich biomass with recombinant bacteria to produce fuel ethanol. Appl Biochem Biotechnol 84-86:141-152

Dunlop MJ, Dossani ZY, Szmidt HL, Chu HC, Lee TS, Keasling JD, Hadi MZ, Mukhopadhyay A (2011) Engineering microbial biofuel tolerance and export using efflux pumps. Mol Syst Biol 7:487-493

Edwards MC, Henriksen ED, Yomano LP, Gardner BC, Sharma LN, Ingram LO, Doran Peterson J (2011) Addition of genes for cellobiase and pectinolytic activity in Escherichia coli for fuel ethanol production from pectin-rich lignocellulosic biomass. Appl Environ Microbiol 77(15):5184-5191

Grohmann K, Bothast RJ (1994) Pectin-rich residues generated by processing of citrus fruits, apples, and sugar beets. In: Himmel ME, Baker JO, Overend RP (eds) Enzymatic conversion of biomass for fuels production, vol 556. American Chemical Society, Washington, pp 372-390

Grohmann K, Baldwin EA, Buslig BS (1994a) Production of ethanol from enzymatically hydrolyzed orange peel by the yeast Saccharomyces cerevisiae. Appl Biochem Biotechnol 45-46:315-327

Grohmann K, Baldwin EA, Buslig BS, Ingram LO (1994b) Fermentation of galacturonic acid and other sugars in orange peel hydrolysates by the ethanologenic strain of Escherichia coli. Biotechnol Lett 16:281-286

Grohmann K, Cameron RG, Buslig BS (1995) Fermentation of sugars in orange peel hydrolysates to ethanol by recombinant Escerichia coli KO11. Appl Biochem Biotechnol 51-52:423-435

Grohmann K, Manthey JA, Cameron RG, Buslig BS (1998) Fermentation of galacturonic acid and pectin-rich materials to ethanol by genetically modified strains of Erwinia. Biotechnol Lett 20:195-200

Gujjari P, Suh S, Houseknecht BB, McKee M, Zhou J (2009) Engineering of yeast strains for broad substrate utilization in alcohol production. Part I: identification of founder strains and gene candidates. 31st Symposium of Biotechnology of Fuels and Fine Chemicals, San Francisco, CA 
Guo G-L, Hsu D-C, Chen W-H, Chen W-H, Hwang W-S (2009) Characterization of enzymatic saccharification for acidpretreated lignocellulosic materials with different lignin composition. Enzyme Microb Technol 45(2):80-87

Hang YD (2006) Management and utilization of food processing wastes. J Food Sci 69(3):104-107

Hang YD, Lee CY, Woodams EE, Cooley HJ (1981) Production of alcohol from apple pomace. Appl Environ Microbiol 42(6):1128-1129

Helander IM, Alakomi H-L, Latva-Kala K, Mattila-Sandholm T, Pol I, Smid EJ, Gorris LGM, von Wright A (1998) Characterization of the action of selected essential oil components on Gram-negative bacteria. J Agric Food Chem 46:3590-3595

Himmel ME, Ding SY, Johnson DK, Adney WS, Nimlos MR, Brady JW, Foust TD (2007) Biomass recalcitrance: engineering plants and enzymes for biofuels production. Science 315(5813):804-807

Jarboe LR, Grabar TB, Yomano LP, Shanmugan KT, Ingram LO (2007) Development of ethanologenic bacteria. Adv Biochem Eng Biotechnol 108:237-261

Joshi VK, Sandhu DK (1996) Preperation and evaluation of an animal feed byproduct produced by solid-state fermentation of apple pomace. Bioresour Technol 56:251-255

Kennedy M, List D, Lu Y, Foo LY, Newman RH, Sims IM, Bain PJS, Hamilton B, Fenton G (1999) Apple pomace and products derived from apple pomace: Use, composition and analysis. In: Linskens HF, Jackson JF (eds) Modern methods of plant analysis, analysis of plant waste materials, vol 20. Springer-Verlag, Berlin, pp 75119

Kim J, Marshall MR, Wei C (1995) Antibacterial activity of some essential oil components against five foodborne pathogens. J Agric Food Chem 43:2839-2845

Koroch AR, Juliani HR (2007) Bioactivity of essential oils and their components. In: Berger RG (ed) Flavours and fragrance: chemistry, bioprocessing and sustainability. Springer, Heidelberg, pp 87-115

Kumar P, Barrett DM, Delwiche MJ, Stroeve P (2009) Methods for pretreatment of lignocellulosic biomass for efficient hydrolysis and biofuel production. Ind Eng Chem Res 48:37133729

Lai X, Davis FC, Hespell RB, Ingram LO (1997) Cloning of cellobiose phosphoenolpyruvate-dependent phosphotransferase genes: functional expression in recombinant Escherichia coli and identification of a putative binding region for disaccharides. Appl Environ Microbiol 63(2):355-363

Lynd LR, Wyman CE, Gerngross TU (1999) Biocommodity engineering. Biotechnol Prog 15(5):777-793

Mann CM, Cox SD, Markham JL (2000) The outer membrane of Pseudomonas aeruginosa NCTC 6749 contributes to its tolerance to the essential oil of Melaleuca alternifolia (tea tree oil). Lett Appl Microbiol 30(4):294-297

McAloon A, Taylor F, Yee W, Ibsen K, Wooley R (2000) Determining the cost of producing ethanol from corn starch and lignocellulosic feedstocks. Nat Renewable Energy Lab Tech Rpt. Goldent, CO, NREL

Micard V, Renard CMGC, Thibault J-F (1996) Enzymatic saccharification of sugar-beet pulp. Enzyme Microb Technol 19:162-170

Mohagheghi A, Evans K, Chou YC, Zhang M (2002) Cofermentation of glucose, xylose, and arabinose by genomic DNA-integrated xylose/arabinose fermenting strain of Zymomonas mobilis AX101. Appl Biochem Biotechnol 98-100:885-898

Mohnen D (2008) Pectin structure and biosynthesis. Curr Opin Plant Biol 11(3):266-277

Narendranath NV, Thomas KC, Ingledew WM (2001) Effects of acetic acid and lactic acid on the growth of Saccharomyces cerevisiae in a minimal medium. J Ind Microbiol Biotechnol 26(3):171-177

Nevoigt E (2008) Progress in metabolic engineering of Saccharomyces cerevisiae. Microbiol Mol Biol Rev 72(3):379-412

Ngadi MO, Correia LR (1992) Kinetics of solid-state ethanol fermentation from apple pomace. J Food Eng 17:97-116
Ohta K, Beall DS, Mejia JP, Shanmugam KT, Ingram LO (1991) Genetic improvement of Escherichia coli for ethanol production: chromosomal integration of Zymomonas mobilis genes encoding pyruvate decarboxylase and alcohol dehydrogenase II. Appl Environ Microbiol 57(4):893-900

O’Neill MA, Ishii T, Albersheim P, Darvill AG (2004) Rhamnogalacturonan II: structure and function of a borate crosslinked cell wall pectic polysaccharide. Annu Rev Plant Biol 55:109-139

Perlack RD, Stokes BJ (2011) U.S. billion-ton update: biomass supply for a bioenergy and bioproducts industry. USDo Energy. Oak Ridge, TN, Oak Ridge National Laboratory: 227

Peterson JD (2006) Ethanol production from agricultural residues. Int Sugar J 108:177-180

Pettersen R (1984) The chemical composition of wood. In: Rowell R (ed) The chemistry of solid wood. American Chemical Society, Washington, pp 57-126

Renard CMGC, Thibault J-F (1993) Structure and properties of apple and sugar-beet pectins extracted by chelating agents. Carbohydr Res 244:99-114

Richard P, Hilditch S (2009) D-galacturonic acid catabolism in microorganisms and its biotechnological relevance. Appl Microbiol Biotechnol 82(4):597-604

Rorick R, Nahar N, Pryor SW (2011) Ethanol production from sugar beet pulp using Escherichia coli KO11 and Saccharomyces cerevisiae. Biol Eng 3:199-209

Sedlak M, Ho NW (2001) Expression of E. coli araBAD operon encoding enzymes for metabolizing L-arabinose in Saccharomyces cerevisiae. Enzyme Microb Technol 28(1):16-24

Shaw PE (1979) Review of quantitative analysis of citrus essential oils. J Agric Food Chem 27:246-257

Spinnler HE, Lavigne B, Blachere H (1986) Pectinolytic activity of Clostridium thermocellum: its use for anaerobic fermentation of sugar beet pulp. Appl Microbiol Biotechnol 23:434-437

Sun J (2007) D-Limonene: safety and clinical applications. Altern Med Rev 12(3):259-264

Sun Y, Cheng J (2002) Hydrolysis of lignocellulosic materials for ethanol production: a review. Bioresour Technol 83(1):1-11

Sutton MD, Peterson JD (2001) Fermentation of sugarbeet pulp for ethanol production using bioengineered Klebsiella oxytoca strain P2. J Sugar Beet Res 38:19-34

Uribe S, Ramirez J, Pena A (1985) Effects of $\beta$-pinene on yeast membrane functions. J Bacteriol 161:1195-1200

van Maris AJ, Abbott DA, Bellissimi E, van den Brink J, Kuyper M, Luttik MA, Wisselink HW, Scheffers WA, van Dijken JP, Pronk JT (2006) Alcoholic fermentation of carbon sources in biomass hydrolysates by Saccharomyces cerevisiae: current status. Antonie Van Leeuwenhoek 90(4):391-418

Vendruscolo F, Albuquerque PM, Streit F, Esposito E, Ninow JL (2008) Apple pomace: a versatile substrate for biotechnological applications. Crit Rev Biotechnol 28(1):1-12

von Loesecke HW (1934) Possibilities of preparing alcoholic citrus beverages. Citrus Ind 15:85-90

Widmer WW, Narciso JA, Grohmann K, Wilkins MR (2009) Simultaneous saccharification and fermentation of orange processing waste to ethanol using Kluyveromyces marxianus. Biol Eng 2:17-29

Widmer W, Zhou W, Grohmann K (2010) Pretreatment effects on orange processing waste for making ethanol by simultaneous saccharification and fermentation. Bioresour Technol 101 (14):5242-5249

Wilkins MR, Suryawati L, Maness NO, Chrz D (2007a) Ethanol production by Saccharomyces cerevisiae and Kluyveromyces marxianus in the presence of orange-peel oil. World J Microbiol Biotechnol 23:1161-1168

Wilkins MR, Widmer WW, Grohmann K (2007b) Simultaneous saccharification and fermentation of citrus peel waste by 
Saccharomyces cerevisiae to produce ethanol. Process Biochem 42:1614-1619

Willats WG, McCartney L, Mackie W, Knox JP (2001) Pectin: cell biology and prospects for functional analysis. Plant Mol Biol 47(1-2):9-27

Wood BE, Ingram LO (1992) Ethanol production from cellobiose, amorphous cellulose, and crystalline cellulose by recombinant Klebsiella oxytoca containing chromosomally integrated Zymomonas mobilis genes for ethanol production and plasmids expressing thermostable cellulase genes from Clostridium thermocellum. Appl Environ Microbiol 58(7):2103-2110

Wooley R, Ruth M, Sheehan J, Ibsen K, Majdeski H, Galvez A (1999)

Lignocellulosic biomass to ethanol process design and economics utilizing co-current dilute acid prehydrolysis and enzymatic hydrolysis current and futuristic scenarios. Nat Renwable Energy Lab Tech Rpt. Golden, CO, NREL

Yomano LP, York SW, Ingram LO (1998) Isolation and characterization of ethanol-tolerant mutants of Escherichia coli KO11 for fuel ethanol production. J Ind Microbiol Biotechnol 20(2):132-138

Zhou W, Widmer W, Grohmann K (2007) Economic analysis of ethanol production from citrus peel waste. Proc Fla State Hort Soc 120:310-315

Zhou W, Widmer W, Grohmann K (2008) Developments in ethanol production from citrus peel waste. Proc Fla State Hort Soc 121:307-310 